\title{
教師志望学生の理科授業についての批評視点に関する研究 一模擬授業についての批評を事例として一
}

$\begin{array}{ll}\text { 杉山 } & \text { 雅俊 } \\ \text { 山崎 } & \text { 敬人 } \\ \end{array}$

\section{【要約】}

教育実習に向けての資質能力の形成について考えた場合，模擬授業は一定の役割を担うも のと考えられる。この模擬授業を対象とした先行研究の多くでは, 教師役の学生の力量形成 に焦点が当てられてきている。しかし, 実際のところ模擬授業で教師役を経験できる回数に は限りがある一方で，览童役として模擬授業に参加し，授業づくりや授業実践のあり方につ いて学ぶ機会が多いことを考慮すれば，授業実践の観察力や分析力等の形成の実態とその向 上のための方策についても検討する必要がある。そこで本研究では，理科の模擬授業に児童 役として参加した教師志望学生の理科授業に関する授業批評視点を明らかにすることを目的 とした。

学生がコメントカードの「良かった点」及び「改善点」として，どのような「内容」につ いて記述しているか，また，どのような「深さ」のレベルで記述しているかについて分析し た結果, 次の 3 点が明らかとなった。

（1）教師志望学生は，模擬授業について批評する際，「良かった点」及び「改善点」のいずれ においても授業者の個別の教授行為を中心に検討していた。それに対して，教材につい て検討した学生は「良かった点」及び「改善点」のいずれにおいても少なく，授業構成 については「改善点」において検討した学生が少なかった。

（2）「良かった点」においては「小学校の授業全般」のレベルで記述する学生が多かった一方 で，「単元固有」のレベルで記述した学生は少ない傾向にあった。

（3）「改善点」においては「単元固有」のレベルで記述した学生が, 他のレベルよりも多いか 同程度であった。

[キーワード] 教員盖成, 小学校理科，模擬授業，授業批評

\section{1. 問題の所在}

2006 年に中央教育審議会によって答申された「今 後の教員養成・免許制度の在り方について」」) では, 教員をめぐる現状と課題について言及され，今後の 教員養成において確実に「教員として最小限必要な 資質能力」を身につけさせることが求められている。 「教員として最小限必要な資質能力」とは，「新たな

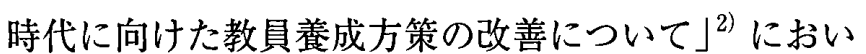
て,「採用当初から学級や教科を担任しつつ, 教科指 導, 生徒指導等の職務を著しい支障が生じることな く実践できる資質能力」と示されている。このよう な資質能力を形成する上で, 教育実習が重要な役割

1 広島大学大学院

2 広島大学大学院教育学研究科
を担っていることは言うまでもない。

一方で，同答申では教育実習に臨む学生に対して も，履修に際しての一定の資質能力を求めており， このことは, 教育実習以前における学部での各授業 の重要性を示しているものと言える。

教員に求められる資質能力のうち，教科指導に関 する資質能力に注目し，教育実習に向けての一定の 資質能力の形成について考えた場合，授業の構想と 実施，改善という授業実践における一連のプロセス を経験するという点で，模擬授業は一定の役割を担 うものと考えられる。

教員養成における模擬授業においては，実際のと ころ, 模擬授業で学生が教師役を経験できる回数に は限りがある。その一方で, 学生は児童役として模 擬授業に参加し，そのなかで授業づくりや授業実践 
杉山・山崎 : 教師志望学生の理科授業についての批評視点に関する研究

の在り方について学ぶ機会が多い。このことを考慮 すれば，教師役の学生を対象として彼らの力量形成 について検討するだけでなく，児童役として参加す る学生を対象として, 模擬授業を通しての彼らの学 びについて検討することも必要であると考えられる。

模擬授業における児童役の学生の学びについて考 えた場合，授業観察の視点がポイントの一つとして 挙げられる。木原ら ${ }^{3)}$ は，小学校教育実習の最初に 指導教員の体育科の授業を観察した際に，観察の観 点を持っていないために何を見ればいいのかわから ないと述べていた教育実習生がいたという研究の成 果 ${ }^{4)}$ から，模擬授業が教育実習の準備として行われ るのであれば，その成果として授業の観察能力の養 成が求められると指摘している。一方, 理科教育学 研究の領域においても，教育実習生と中堅教員との 理科授業に対する自己分析内容を比較した吉田・西 島 $^{5)}$ が，教育実習生は自らの授業実践を分析する際， 分析視点を与えないと授業者自身の動きについての 分析や反省が多くなる傾向が見られたことを報告し ている。実習生が授業の何を見ればいいのかわから ないという実態は理科授業にも当てはまることであ り，模擬授業において授業の観察能力の養成が求め られるという指摘は，理科教師教育にも当てはまる ものであると考えられる。

理科教育学研究の領域において模擬授業を対象と した研究として, 観察・実験の位置付いた理科の模 擬授業実践に関する受講学生の資質能力の变容につ いて調查した三崎 $\left.{ }^{6}\right)$ や，模擬授業経験による学生 の意識変化を調査した佐藤ら ${ }^{7)}$, 授業での様子や事 後レポートの質的分析によって模擬授業を取り入れ た理科の必修科目の成果と課題を検討した伊佐・石 井 $^{8)}$ や石井ら ${ }^{9)}$ といったものが挙げられるが, これ らの研究は，主に教師役経験による力量形成に焦点 が当てられたものである。また，理科授業に関する 授業観察の視点を養うことを目指したこれまでの先 行研究として, 德永 ${ }^{10)}$ や中山ら ${ }^{11)}$, 阪元ら ${ }^{12)}$, 山口 $ら^{13)}$ ，土田ら ${ }^{14)}$ といったものが挙げられる。しかし ながら、これらの研究では授業を第三者の立場とし て観察したときの授業観察の視点を対象としている。 模擬授業における児童役の学生は，当事者として授 業に参加しており，学習者の視点で授業づくりや授 業実践の在り方について学ぶこととなる。彼らを対 象とした場合には，そのことを考慮した上で調查を 行う必要があると考えられるが，そのような研究は これまで行われていない。

そこで本研究では，理科の模擬授業に児童役とし て参加した教師志望学生の理科授業に関する授業観
察における視点を明らかにすることを目的とする。 本研究では, 児童役の学生が記述した「コメント カード」を分析の資料としている（「2.3. 分析資料お よび分析対象」で後述する）が，授業観察の際に記 録を残すという行為は意識的な行為であり，そこに は対象者の批評が含まれているものと考えられる。 こうした認識により，本研究では，「授業批評視点」 として教師志望学生の授業の捉え方を検討すること とする。授業批評視点は, 対象者の評価の在りよう も含めているという点で, 従来の授業観察視点より も狭義の概念と捉えている。

\section{2. 方法}

\section{1 対象授業および対象者}

本研究では, $\mathrm{A}$ 大学の初等教育教員養成コース 3 年次第 5 セメスターに開講されていた, 小学校理科 の指導に関する選択科目である「初等理科授業研究」 の受講生を対象とした。受講生は小学校の教師を志 望する学生で, 教育実習は未経験であった。この講 義は 2 名の指導教員が受け持ち, 受講生を 2 クラス に分けて実施した。本研究で対象としたのは，その うちの 1 クラスの学生 54 名であった。

\section{2 「初等理科授業研究」の概要}

本研究で対象とした「初等理科授業研究」は，小 学校理科の授業計画を立案し, 模擬授業として実践 することなどを通して，理科授業のあり方を理論と 実践の両面から考察し, 理科授業を構想・実践し改 善していく力量を育成することが目標であった。講 義は, 3 回に渡りガイダンス等を実施した後, 計 13 回の模擬授業を行った。表 1 には，模擬授業を実施 した全 13 回の概要を示している。受講生は, 4〜5 名で 1 つの班を編成し, 小学校理科の授業単元から 1 つを選び，その単元中の 1 時間分の授業を構想し た。 1 回の授業は 45 分とし, 模擬授業実施班のうち の 1 名が教師役を担う方法と, 実施班の複数のメン バーが交代で担当する方法のどちらかを選択させ, 実施班の教師役以外の学生は必要に応じて机間指導 を行い，教師役の学生を支援した。

\section{3 分析資料および分析対象}

実施班以外の受講生は児童役として参加し，模擬 授業実施後， 15 分程度の時間で授業の「良かったと 思う点」(以下，「良かった点」）と「工夫や改善が必 要だと思う点/代替案など」(以下,「改善点」) を, それぞれの見出しの下に数行程度の記述スペースを 設けた「コメントカード」の用紙に自由記述した。 
本研究では，このコメントカードを分析の資料とし た。コメントカードの記入様式は自由であったため, 学生によって筒条書きで記すものと文章によって記 すものという違いが見られた。そこで, 箇条書きで あるものはそれをひとつと数え，文章については意 味のまとまりごとに区分してひとつと数えた。

分析対象の選択に際しては, 模擬授業を繰り返し 批評するなかで授業批評視点が変容する可能性があ ること，扱う学年や教林により異なる視点で授業を 批評する可能性があることを念頭に抽き，まず，模 擬授業の開始時（第 1 回）と終了時（第 13 回）に加 え, 終了時の児童役の学生が他の回より少なかった ことを考慮してその直前の第 12 回も分析対象とし た。その上で、できるだけ異なる学年の模擬授業が 含まれるようにすることと，できるだけ理科の異な る内容区分の単元が含まれるようにすることを考慮 して，分析対象を選択した。以上の手続きにより， 模擬授業を行った全 13 回のなかから 6 回分を選択し た。分析対象とした回については，表 1 に網掛けで 宗している。

\section{4 分析方法}

本研究では，教師志望学生の理科授業に関する批 評視点について量的な知見を得るため, 山口ら ${ }^{15)}$ の 方法に準扰し，(1) コメントカードにどのような 「内容」を記述しているのか，(2）コメントカードに どのような「深さ」で記述しているのか，について 明らかにすることに取り組んだ。具体的な手順等は 下記の通りである。

「内容」の分析に祭して，山口ら ${ }^{16)}$ は Davis ${ }^{17)} の$
研究を参考にして作成したカテゴリに基づいて分析 を行ったが，Davisや山口らの研究が教授資料からの 学習の内容を明らかにすることを目的としたのに対 して, 本研究では模擬授業についての批評視点の内 容を明らかにすることを目的としているため，山口 らの用いたカテゴりを応用することは難しいと考え た。そこで、コメントカードの記述内容を $\mathrm{KJ}$ 法的手

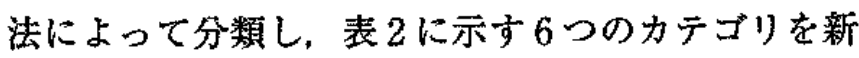
たに作成した。

なお，カテゴリの作成に祭しては，まず，第一著 者が第 1 回のコメントカードの記述内容について KJ 法的手法により分類し，喻名及び定義付けを行った。 その後，第二著者にカテゴリとともに分類結果を提 示し，第二著者が異なる分類を行った記述について 両者で協議を行い，協議の上で一致あるいはカテゴ リの䝵加・修正を行った。カテゴリの追加・修正が あった場合には，すべての記述について再度見直し， 修正・協議を行い，記述の分類を決定した。

ここで，本研究で設定された6つのカデヨ゙リにつ いて，先行研究に技けるカテゴリと対比して検討し ておきたい。教師志望学生の授業観察視点を対象と した研究として，梅澤 ${ }^{18)}$ や三島 ${ }^{19)}$, 理科授業に特定


られる。それらのうち，梅澤では，デジタルカメラ を用いて対象者が撮影した画像㧍よび対象者への撮 影意図のインタビュー記録から，土田らでは，ビデ オカメラを用いて対象者が記録した映像を分析資料 としており、三島や中山らでは，学生の記述内容を 分析資料としている。梅澤や土田らと本研究では分 析の資料が巽なるため，三島と中山らと対比するこ

表 1 模擬授業実施全 13 回の概要

\begin{tabular}{|c|c|c|c|c|c|}
\hline \multirow{2}{*}{ 回 } & \multirow{2}{*}{ 班 } & \multirow{2}{*}{ 単元 } & \multirow{2}{*}{ 児童役の人数 } & \multicolumn{2}{|c|}{ 記述数 } \\
\hline & & & & 良かった点 & 改搃点 \\
\hline 第 1 国 & 第 1 & 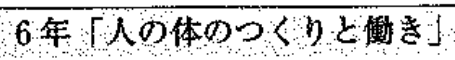 & 48 & 168 & 140 \\
\hline 第 2 回 & 第 2 班 & 6 年「水溶液の性賀」 & 41 & 162 & 158 \\
\hline 第 3 回 & 第 3 班 & 3 年「風やゴムの働き」 & 44 & 158 & 156 \\
\hline 第 4 回 & 第 4 班 & 4 年「金属，水，空気と温度」 & 45 & 164 & 158 \\
\hline 第 5 回 & 第 5 理 & 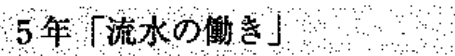 & 46 & 165 & 207 \\
\hline 第 6 回 & 第 6 班 & 6 年「てこの規則性」 & 47 & 129 & 167 \\
\hline 第 & 第 7 斑 & 3 年ा電缚 $几$ 道 & 44 & 180 & 126 \\
\hline 第 8 回 & 第 8 班 & 3 年「磁石の性賈」 & 46 & 163 & 130 \\
\hline 第 9 I & 第 9 琻 & 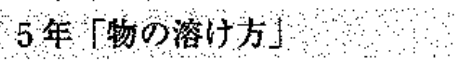 & 42 & 158 & 132 \\
\hline 第 10 回 & 第 10 班 & 4年「月と星」 & 42 & 134 & 125 \\
\hline 第 11 回 & 第 11 班 & 4 年「空気と水の性質」 & 45 & 139 & 146 \\
\hline 第 12 回 & 第 12 理 & 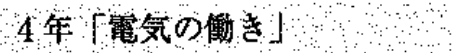 & 44 & 150 & 112 \\
\hline 梯 13 回 & 第 13 班. & 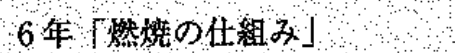 & 34 & 120 & 97 \\
\hline
\end{tabular}


杉山・山崎 : 教師志望学生の理科授業についての批評視点に関する研究

表 2 内容に関するカテゴリと記述例

\begin{tabular}{|c|c|c|}
\hline カテゴリ & 定義 & 記述例 \\
\hline 教材 & $\begin{array}{l}\text { 観察・実験の内容や観察・実験における安全面 } \\
\text { の配慮についてなど, 教材の学び方に関わる記 } \\
\text { 述。 }\end{array}$ & $\begin{array}{l}\text { ·食塩の水への溶け方が目で見てしっかり分かる実験 } \\
\text { だったのが, 良かったです。 } \\
\text { ·折り紙など, 子どもの興味をひくものを調べるもの } \\
\text { にしていたので, 興味をもって実験に臨めた。 }\end{array}$ \\
\hline 教授 & $\begin{array}{l}\text { 児童役の意見への対応や, 説明や指示の内容, } \\
\text { 演示の仕方といった, 授業者の個別の教授行為 } \\
\text { に関わる記述。 }\end{array}$ & $\begin{array}{l}\text { ・正しくない意見にもちゃんと対応していてすごいと } \\
\text { 思った。 } \\
\text { ・ワークシートと同じ位置でモデルがやってくれたの } \\
\text { で見やすかった。 }\end{array}$ \\
\hline 授業棈成 & $\begin{array}{l}\text { 授業全体について，授業の組立，時間配分など, } \\
\text { マクロな視点で授業を評価している記述。 }\end{array}$ & $\begin{array}{l}\text { ・全体としてとても丁寧な授業だと感じました。 } \\
\cdot \text { 気体検知管をつかった結果の情報から実験の結果を } \\
\text { 考えさせて実験という流れが良かったです。 }\end{array}$ \\
\hline 教具 & $\begin{array}{l}\text { ワークシートや板書, 掲示物についての内容· } \\
\text { 活用法に関わる記述。 }\end{array}$ & $\begin{array}{c}\text { ・聴診器が少ないことを考慮し, 他の児童には別の } \\
\text { ワークシートを取り組ませるようにしていたところ。 } \\
\text { ・ワークシートがわかりやすく書きやすい形だった。 }\end{array}$ \\
\hline 教師の振 & $\begin{array}{l}\text { 授業者の話し方や, 姿勢など, 授業内容と関わ } \\
\text { らない教師の在り方に関する記述。 }\end{array}$ & $\begin{array}{l}\text { 声がききとりやすくてよかった。 } \\
\text { 生徒が発表するときもきちんとその子の方を向いて } \\
\text { いて, 生徒の話がすんでから板書をしていた。 }\end{array}$ \\
\hline その他 & 上記の $5 つ に$ 当てはまらない記述。 & $\begin{array}{l}\text { ・単元の戦略が非常に詳しく書いてあって良かった。 } \\
\text { • 授業前, 黑板をすごく丁寧にふいていた。 }\end{array}$ \\
\hline
\end{tabular}

ととした。

まず，「教材」については，三島の「教材」にほ ほ相当するものと考えられる。また，中山らの「授 業の組み立て」の下位観点として含まれている「観 察・実験」に相当するものであると考えられる。

「教授」と「教師の振る舞い」はともに教師行動に ついてのカテゴリである。このうち「教授」は中山 らの「指導法」に近いカテゴリであると考えられる が,「指導法」には下位観点として「声の大きさ・調 子」や「アイコンタクト」という項目が含まれてお り，これらは本研究では「教師の振る舞い」として 単独で設定されている。また，三島では教師行動に 関して「教師対応」というカテゴリが設定されてお り，これは「教授」と「教師の振る舞い」の両方を あわせたものに相当すると考えられる。

「授業構成」については，三島の「本時の授業構 成」と「単元授業構成」をあわせたものに相当する が, 三島が「単元授業構成」で注目した点について は, 本研究では後述する「深さ」のレベルの分析に 際して検討することができると考えられる。また, このカテゴリは中山らの「授業の組み立て」にも相 当するものであると考えるが，「授業の組み立て」に は下位観点として「観察・実験」が含まれているの に対して，本研究では観察・実験については「教材」 カテゴリに含めているため「授業構成」には含まれ
ていない。

「教具」は，三島の「黒板使用法」に近いと考えら れるが,「黒板使用法」は黒板に限定されているのに 対して，「教具」は模擬授業で使用されたワークシー トや掲示物等についての記述も含めたカテゴリであ る。中山らは「指導法」の下位観点として「揭示物 と発問」・「板書（タイミング，内容，レイアウト)」 を位置付けているが, これらの下位観点のうち「発 問」以外のものは本研究では「教具」に含まれてい る。中山らの「掲示物と発問」のうち「発問」につ いては，本研究では「教授」に含まれている。

なお，中山らでは「教科学習に関わる児童生徒の 実態」として，三島では「子ども」として，それぞ れ学習者についてのカテゴリが設定されている。授 業観察の際に学習者の状況を把握することは重要な ことであるが, 本研究は模擬授業をフィールドとし ており, 調査対象者は観察者としてではなく児童役 として参加していたため, 学習者の理解や思い等は, 「教授」や「教材」等授業を構成する要素について批 評するなかに表象していたと思われる。そのため, 学習者に関するカテゴリは設定されなかった。少数 ではあるが，実際の子どもの実態への疑問を記した 記述が見られたが，そのような記述は「その他」に 分類された。「その他」カテゴリについてはこのほ か, 中山らの「学習環境の整備」のような教室環境 
表 3 深さに関するレベルと記述例

\begin{tabular}{|c|c|c|}
\hline レベル & 定義（山口ら，2009） & 本研究での記述例 \\
\hline 小学校の授業全般 & $\begin{array}{l}\text { 小学校の各種の教科に関する教授技術などに言 } \\
\text { 及しているものの, 理科という教科ならではの } \\
\text { 記述になっていない回答。 }\end{array}$ & $\begin{array}{l}\text { ワークシートで静かにさせる, という発想は新 } \\
\text { 鮮でした。 }\end{array}$ \\
\hline 理科授業全般 & $\begin{array}{l}\text { 小学校理科の授業に特徴的な教授技術などに言 } \\
\text { 及しているものの, 当該単元ならではの記述に } \\
\text { なっておらず, 他の単元にも共通する事項を記 } \\
\text { 述した回答。 }\end{array}$ & $\begin{array}{l}\text { 疑問がでたら，もう一度実験して確かめられる } \\
\text { ところ。 }\end{array}$ \\
\hline 単元固有 & $\begin{array}{l}\text { 当該単元に固有な教授技術や教材や指導上の留 } \\
\text { 意点などを記述した回答。 }\end{array}$ & $\begin{array}{l}\text { 手首の脈拍と心臓を同時に聞く実験によって, 腕 } \\
\text { をにぎった時の比較がすごくしやすかっです。 }\end{array}$ \\
\hline
\end{tabular}

の設定や授業準備に関わる記述，および模擬授業の 機能に関わる記述等が含まれるとともに，上記 $5 つ$ のカテゴリのいずれにも分類が困難であった記述も 含まれている。

次に,「深さ」については, 表 3 に示すような, 山 口ら ${ }^{22)}$ の設定した「小学校の授業全般」,「理科授業 全般」及び「単元固有」という 3 つのレベルに準拠 し, 記述内容を分類した。ここでの分析においても, 第一著者が分類を行った後, その結果について第二著 者が検討し，両者で不一致であった場合については 協議の上で一致させた。なお，ここでの分析は「内 容」分析と異なりレベルの追加は行われなかった。

以上のような手続きの後, 設定された「内容」カ テゴリと「深さ」レベルが調査対象者の記述に認め られるかどうかについて再度分析し，各カテゴリや 各レベルの人数を集計した。人数による分析とした のは, 対象者一人一人の記述傾向を回ごとに整理す ることで, 教師志望学生の批評視点の実態に接近で きると考えたためである。

\section{3. 結果と考察}

本研究で設定した「内容」カテゴリと山口ら ${ }^{23)}$ の 「深さ」レベルによる「良かった点」と「改善点」そ れぞれの分析結果より, 調查対象者の授業批評視点 の実態について検討する。

なお，設定された「内容」カテゴリのうち，理科 授業に関わる内容が含まれるカテゴリは，観察・実 験の内容についての記述などが含まれる「教材」と, 観察・実験の結果の整理の仕方や児童の思考を促す ための支援等についての記述などが含まれる「教 授」，児童に科学概念を獲得させるための効果的な授 業形態についての記述などが含まれる「授業構成」 の 3 つである。そこで,「深さ」分析に際しては, 以 上の 3 つのカテゴリを中心に検討を行った。

\section{1 「良かった点」に関する記述人数}

\subsection{1 内容と深さの回答傾向}

表 4 には，「良かった点」に関する「内容」の各力 テゴリの人数の集計結果とともに，「教材」，「教授」, 「授業構成」の 3 つのテゴリについては「深さ」の 各レベルの人数の内訳も示している。

表 4 からわかるように，「教材」について記述した 人数は, $76.1 \%$ あ゙あた第 5 回を除いて 4 割に満た なかった。また，「深さ」の内訳を見ると，第 5 回を 除く回で「理科授業全般」の方が「単元固有」より も多いか同程度の傾向を示しており,「単元固有」の 視点から「教材」について記述した人数は，第 5 回 を除いて 1 割前後であった。つまり，「教材」に関 わって授業の「良かった点」を記述する調查対象者 は少なく，記述した学生であっても，その多くが単 に観察・実験が扔もしろかったことや安全面が配慮 されていたことなど，理科授業全般に関わる内容に とどまり，例えば模擬授業実施班が扱った観察・実 験の内容が当該単元を学ぶにあたってどのような役 割を果たしたのかといった，当該単元における学び の在り方と観察・実験の機能とを結びつけて具体的 に記述したものは少なかったのである。一方，第 5 回では， 7 割を超える対象者が「教材」について記 述し，「単元固有」の視点からも5 割が記述していた が, ここで, 他の回と第 5 回で相違が認められた要 因について検討してみたい。まず 第 5 回以外の回か ら検討すると，例えば第 9 回の「物の溶け方」では シュリーレン現象の観察をもとに食塩の溶け方を考 えさせたり，第 13 回の「燃焼の仕組み」では酸素・ 絰素・二酸化炭素それぞれで満たされた集気瓶中で の線香の燃え方を扱ったりと，模擬授業で扱われた 教材の多くが教科書で取り扱われているような, 学 生にとって既知，あるいは理解が容易と考えられる 内容であった。そのため, 教材が学生にとって既に 
杉山・山崎 : 教師志望学生の理科授業についての批評視点に関する研究

表 4 「良かった点」の内容と深さに関する記述人数

\begin{tabular}{|c|c|c|c|c|c|c|c|c|c|}
\hline & \multicolumn{2}{|c|}{ 第 1 回 } & \multicolumn{2}{|c|}{ 第 5 回 } & \multicolumn{2}{|r|}{ 第 7 回 } & 第 9 回 & 第 12 回 & 第13 回 \\
\hline 教材 & 16 & (33.3\%) & & (76.1\%) & & (34.1\%) & $12(28.6 \%)$ & $11(25.0 \%)$ & $6(17.6 \%)$ \\
\hline 小学校の授業全般 & 0 & $(0.0 \%)$ & 1 & $(2.2 \%)$ & 3 & $(6.8 \%)$ & $1 \quad(2.4 \%)$ & $1 \quad(2.3 \%)$ & $(0.0 \%)$ \\
\hline 理科授業全般 & 10 & $(20.8 \%)$ & 18 & $(39.1 \%)$ & & $(15.9 \%)$ & $7(16.7 \%)$ & $5(11.4 \%)$ & $5(14.7 \%)$ \\
\hline 単元固有 & 6 & $(12.5 \%)$ & 24 & $(52.2 \%)$ & 7 & $(15.9 \%)$ & $4 \quad(9.5 \%)$ & $5(11.4 \%)$ & $1 \quad(2.9 \%)$ \\
\hline 教授 & 33 & $(68.8 \%)$ & 28 & $(60.9 \%)$ & 33 & $(75.0 \%)$ & $31 \quad(73.8 \%)$ & $28(63.6 \%)$ & $29(85.3 \%)$ \\
\hline 小学校 $\sigma$ & 25 & $(52.1 \%)$ & 8 & $(17.4 \%)$ & 31 & $(70.5 \%)$ & $29(69.0 \%)$ & $18(40.9 \%)$ & $23(67.6 \%)$ \\
\hline 理科授業全般 & 9 & $(18.8 \%)$ & 18 & $(39.1 \%)$ & 12 & $(27.3 \%)$ & $8(19.0 \%)$ & $8(18.2 \%)$ & $10(29.4 \%)$ \\
\hline 単元固有 & 4 & $(8.3 \%)$ & 9 & $(19.6 \%)$ & $\underline{0}$ & $(0.0 \%)$ & $4 \quad(9.5 \%)$ & $8(18.2 \%)$ & $3 \quad(8.8 \%)$ \\
\hline 授業構成 & 13 & $(27.1 \%)$ & 12 & $(26.1 \%)$ & 31 & $(70.4 \%)$ & $19(45.2 \%)$ & $29(65.9 \%)$ & $15(44.1 \%)$ \\
\hline 小学校の授業全般 & 8 & $(16.7 \%)$ & 10 & $(21.7 \%)$ & 27 & $(61.4 \%)$ & $11(26.2 \%)$ & $18(40.9 \%)$ & $6(17.6 \%)$ \\
\hline 理科授 & 3 & $(6.3 \%)$ & 1 & $(2.2 \%)$ & & $(13.6 \%)$ & $7(16.7 \%)$ & $12(27.3 \%)$ & $10(29.4 \%)$ \\
\hline 単元固有 & 2 & $(4.2 \%)$ & 2 & $(4.3 \%)$ & 2 & $(4.5 \%)$ & $3 \quad(7.1 \%)$ & $5(11.4 \%)$ & $0 \quad(0.0 \%)$ \\
\hline 教具 & 33 & $(68.8 \%)$ & 19 & (41.3\%) & 27 & $(61.4 \%)$ & $30(71.4 \%)$ & $26 \quad(59.1 \%)$ & $16(47.1 \%)$ \\
\hline 教師の振 & 19 & $(39.6 \%)$ & 12 & $(26.1 \%)$ & & $(18.2 \%)$ & $10(23.8 \%)$ & $12(27.3 \%)$ & $10(29.4 \%)$ \\
\hline その他 & 9 & $(18.8 \%)$ & 12 & $(26.1 \%)$ & & $(13.6 \%)$ & $4 \quad(9.5 \%)$ & $\begin{array}{ll}4 & (9.1 \%) \\
\end{array}$ & $7(20.6 \%)$ \\
\hline
\end{tabular}

知り得たもの，あるいは理解が容易なものであり， 「教材」の視点から「良かった点」について検討する ことが少ない結果となったのではないかと考えられ る。それに対して第 5 回では,「流水のはたらき」を 学ぶ際の教材として自作教材のミニチュアモデルを 活用して㧍り，児童役の学生にとって新奇なもので あった。このように，学生にとって新奇で新たな学 びの対象となるような教材が用いられた場合には, 当該単元の内容と結びつけた肯定的評価が多い傾向 にあることを示唆しているものと考えられる。

「教授」については，分析の対象としたすべての回 で 6 割以上の調查対象者が記述していた。しかしな がら，「深さ」について見ると，第 5 回を除いた回で 「小学校の授業全般」についての記述人数が多い傾向 にあり，その一方で，「単元固有」の「教授」につい て記述していた人数は，分析の対象としたすべての 回で 2 割に満たなかった。つまり，「良かった点」と して「教授」について記述する調查対象者は多かっ たものの，そのほとんどが, 例えば学習者の意見に 対しての反応が良かったことや授業の中で多くの問 いかけがあったことなど，理科授業固有ではない各 教科共通の内容について記述した者であり, 当該単 元に関わる学習者の知識や思考を踏まえて授業者が どのような発問を行ったかなどといった単元固有の 内容に関わる教授行為について記述した調查対象者 は少なかった。

「授業構成」については，第 1 回と第 5 回では 3 割 に満たなかったものの, その他の回では比較的多く の人数が記述していた。しかしながら，「教授」と同
様に,「単元固有」の視点から記述している人数は少 なく、およそ 1 割あるいは 1 割未満であった。

「教具」については，分析の対象としたすべての 回で 4 割以上の調查対象者が記述しており, 特に第 1 回と第 9 回では約 7 割が記述していた。また，第 5 回を除くすべての回で「教材」よりも多い傾向と なっていた。

「教師の振る舞い」については，第 1 回では約 4 割 の調查対象者が記述していたものの, 他の回では 3 割に満たなかった。約 4 割を記述していた第 1 回を 含むすべての回で「教授」より少ない傾向となって いた。

\section{1 .2 深さのみの回答傾向}

ここでは，どの「内容」カテゴリの観点で記述し ていたかとは関係なく，どの「深さ」のレベルで記 述していたのかについて分析するために，各回にお いて「深さ」の各レベルの記述が認められた人数を 集計し，その結果を表 5 に示した。

表 5 の通り，「小学校の授業全般」は第 5 回以外で 約 9 割の学生が記述しており,「理科授業全般」は約 5 割の学生が記述しており,「単元固有」は第 5 回と 第 10 回を除く回で約 2 割であった。各回におけるレ ベルごとの記述人数を比較するために $\chi^{2}$ 検定を行っ たところ，第 5 回以外の回でレベルごとの記述人数 の偏りは有意であった。残差分析（表 6）によると, 分析の対象となったすべての回で「小学校の授業全 般」についての記述人数が有意に多く，「単元固有」 についての記述人数が有意に少なかった。これより， 
表 5 「良かった点」の深さに関する記述人数

\begin{tabular}{lccrrrrr}
\hline & 第 1 回 & \multicolumn{1}{c}{ 第 5 回 } & \multicolumn{1}{c}{ 第 7 回 } & \multicolumn{1}{c}{ 第 9 回 } & \multicolumn{2}{c}{ 第 12 回 } & \multicolumn{1}{c}{ 第 13 回 } \\
\hline 小学校の授業全般 & $44(91.7 \%)$ & $31(67.4 \%)$ & $43(97.7 \%)$ & $39(92.9 \%)$ & $39(88.6 \%)$ & $30(88.2 \%)$ \\
理科授業全般 & $24(50.0 \%)$ & $32(69.6 \%)$ & $19(43.2 \%)$ & $19(45.2 \%)$ & $22(50.0 \%)$ & $23(67.6 \%)$ \\
単元固有 & $11(22.9 \%)$ & $30(65.2 \%)$ & $9(20.5 \%)$ & $11(26.2 \%)$ & $18(40.9 \%)$ & $7(20.6 \%)$ \\
\hline
\end{tabular}

表 6 「良かった点」の深さについての残差分析の結果

\begin{tabular}{|c|c|c|c|c|c|c|c|c|c|c|}
\hline \multirow[b]{3}{*}{$\begin{array}{c}\text { レベルの記述 } \\
\text { の有無 }\end{array}$} & \multicolumn{2}{|c|}{ 第 1 回 } & \multicolumn{2}{|c|}{ 第 7 回 } & \multicolumn{2}{|c|}{ 第 9 回 } & \multicolumn{2}{|c|}{ 第 12 回 } & \multicolumn{2}{|c|}{ 第 13 回 } \\
\hline & $\chi^{2}(2)=46$ & $50, \mathrm{p}<.01$ & $\chi^{2}(2)=5$ & $84, p<.01$ & $\chi^{2}(2)=35$ & $61, \mathrm{p}<.01$ & $\chi^{2}(2)=2$ & $52, \mathrm{p}<.01$ & $\chi^{2}(2)=33$ & $76, \mathrm{p}<.01$ \\
\hline & 有 & 無 & 有 & 無 & 有 & 無 & 有 & 無 & 有 & 無 \\
\hline $\begin{array}{c}\text { 小学校の授業 } \\
\text { 全般 }\end{array}$ & $6.28 * *$ & $-6.28^{* *}$ & $7.16^{* *}$ & $-7.16^{* *}$ & $5.71^{* *}$ & $-5.71^{* *}$ & $4.77^{* * *}$ & $-4.77 * *$ & $4.27^{* *}$ & $-4.27^{* *}$ \\
\hline 理科授業全般 & -0.83 & 0.83 & $-1.73^{+}$ & $1.73^{+}$ & -1.38 & 1.38 & -1.63 & 1.63 & 1.28 & -1.28 \\
\hline 単元固有 & $-5.45^{* *}$ & $5.45^{* *}$ & $-5.43^{* *}$ & $5.43^{* *}$ & $-4.40^{* *}$ & $4.40^{* *}$ & $-3.14^{* *}$ & $3.14^{* *}$ & $-5.55^{* *}$ & $5.55^{* *}$ \\
\hline
\end{tabular}

第 5 回を除いたすべての回で,「小学校の授業全般」 の視点から児童役として参加した授業についての良 かった点を見いだした調査対象者が多かった一方で, 「単元固有」の視点から児童役として参加した授業に ついての良かった点を見いだした調查対象者は少な かったことがわかる。

山口ら ${ }^{24)}$ は, 小学校教師志望学生を対象とし, 教 授資料からの学習を事例として, 理科を教えること についての学習能力を実証的に明らかにしている。 教授資料を読んだ上で自由記述された「指導案を考 える上で参考になる点」と「その理由」の回答を資 料とし，教授資料から学習した「内容」と「梁さ」 について分析した結果, 調査対象者の約 $90 \%$ が理 科授業全般」を回答していた一方で，「単元固有」に ついて回答した調查対象者は全体の約 $40 \%$ に過ぎな かったことを報告している。本研究では模擬授業に 児童役として参加した学生の授業批評視点について 検討しており, 学習能力について検討した山口らと は研究対象が異なるものの, 「単元固有」が少なかっ たという点について山口らと一致する結果が得られ たと言える。

\section{2 「改善点」に関する記述人数}

\section{2 .1 内容と深さの回答傾向}

表 7 には，「改善点」に関する「内容」の各カテゴ リの人数の集計結果とともに,「教材」,「教授」,「授 業構成」の3つのカテゴリについては「深さ」の各 レベルの人数の内訳も示している。

表 7 からわかるように，「教材」については，第 5
回では $58.7 \%$ であったが, 他の回では 3 割に満たな かった。第 5 回が他の回よりも多い傾向にあった要 因について検討すると, この回が自作のミニチュア モデルを用いていたことは先に述べた通りであるが, このモデル実験には精度上の問題があったためにグ ループによる実験誤差が生じてしまい, その点での 改善が必要だと考えた学生が多数いたためであると 考えられる。一方, 他の回では 3 割に満たなかった ことについて検討すると, 模擬授業で扱われた教材 の多くが学生にとって既知, あるいは理解が容易と 考えられる内容であったことは先に述べた通りであ るが, このような内容のため観察・実験もスムーズ に進行できたものと考えられる。つまり, 対象者に おいては, 第 5 回のように自作教材を扱うことなど によって，特に観察・実験の精度が問題となる場合 であれば「教材」の視点から改善点を指摘しやすく なるものの, 彼らにとって既知の内容である場合に は, 当該単元を踏まえた観察・実験の問題点や改善 策を提案するなど,「教材」の視点から授業の改善点 を検討することが少ないものと考えられる。仮説実 験授業のビデオ記録を用いて大学生の授業批評能力 を調査した德永 ${ }^{25)}$ は, 学生から教材に対する提案や 生徒実験の実施を求める意見が出されたものの, そ の数および内容はそしいものであったことを指摘し ており，「教材」についての「改善点」を記述した人 数が少なかったという本研究の結果は德永の結果と 符合するものであった。

「教授」については, 分析の対象としたすべての回 で 7 割以上であった。すでに指摘したような，「良 
杉山・山崎：教師志望学生の理科授業についての批評視点に関する研究

表 7 「改善点」の内容と深さに関する記述人数

\begin{tabular}{|c|c|c|c|c|c|c|c|c|c|c|}
\hline \multirow{2}{*}{ 教材 } & \multicolumn{2}{|c|}{ 第 1 回 } & \multicolumn{2}{|c|}{ 第 5 回 } & \multicolumn{2}{|r|}{ 第 7 回 } & \multicolumn{2}{|r|}{ 第 9 回 } & 第 12 回 & 第 13 回 \\
\hline & & (29.2\%) & & $(58.7 \%)$ & 12 & $(27.3 \%)$ & & $(11.9 \%)$ & $11(25.0 \%)$ & $9(26.5 \%)$ \\
\hline 小学校の授業全般 & 0 & $(0.0 \%)$ & 1 & $(2.2 \%)$ & 0 & $(0.0 \%)$ & 0 & $(0.0 \%)$ & $(0.0 \%)$ & $2 \quad(5.9 \%)$ \\
\hline 理科授業全般 & & $(10.4 \%)$ & 10 & (21.7\%) & 2 & $(4.5 \%)$ & 0 & $(0.0 \%)$ & $5(11.4 \%)$ & $1 \quad(2.9 \%)$ \\
\hline 単元固有 & 10 & $(20.8 \%)$ & 19 & $(41.3 \%)$ & 11 & $(25.0 \%)$ & 5 & $(11.9 \%)$ & $7(15.9 \%)$ & $6(17.6 \%)$ \\
\hline 教授 & 36 & $(75.0 \%)$ & 44 & $(95.7 \%)$ & 35 & $(79.5 \%)$ & 39 & $(92.9 \%)$ & $34(77.3 \%)$ & $27(79.4 \%)$ \\
\hline 小学校の授業全般 & 16 & $(33.3 \%)$ & 25 & $(54.3 \%)$ & 19 & $(43.2 \%)$ & 16 & $(38.1 \%)$ & $11(25.0 \%)$ & $12(35.3 \%)$ \\
\hline 理科授業全般 & 13 & $(27.1 \%)$ & 23 & $(50.0 \%)$ & 17 & $(38.6 \%)$ & 16 & $(38.1 \%)$ & $11(25.0 \%)$ & $17(50.0 \%)$ \\
\hline 単元固有 & 18 & $(37.5 \%)$ & 23 & $(50.0 \%)$ & 12 & $(27.3 \%)$ & 23 & $(54.8 \%)$ & $21 \quad(47.7 \%)$ & $5(14.7 \%)$ \\
\hline 授業構成 & 8 & $(16.7 \%)$ & 21 & $(45.7 \%)$ & 15 & $(34.1 \%)$ & 17 & $(40.5 \%)$ & $10(22.7 \%)$ & $12(35.3 \%)$ \\
\hline 小学校の授業全般 & 3 & $(6.3 \%)$ & 6 & $(13.0 \%)$ & 3 & $(6.8 \%)$ & 4 & $(9.5 \%)$ & $1 \quad(2.3 \%)$ & $6(17.6 \%)$ \\
\hline 理科授業全般 & 2 & $(4.2 \%)$ & 5 & (10.9\%) & & $(11.4 \%)$ & 3 & $(7.1 \%)$ & $6(13.6 \%)$ & $4(11.8 \%)$ \\
\hline 単元固有 & 3 & $(6.3 \%)$ & 11 & $(23.9 \%)$ & 8 & $(18.2 \%)$ & 10 & $(23.8 \%)$ & $3 \quad(6.8 \%)$ & $2 \quad(5.9 \%)$ \\
\hline $\begin{array}{l}\text { 教具 } \\
\end{array}$ & 28 & $(58.3 \%)$ & 29 & $(63.0 \%)$ & 13 & $(29.5 \%)$ & 12 & $(28.6 \%)$ & $18(40.9 \%)$ & $14(41.2 \%)$ \\
\hline 教師の振る舞い & 4 & $(8.3 \%)$ & 5 & $(10.9 \%)$ & & $(2.3 \%)$ & 2 & $(4.8 \%)$ & $3 \quad(6.8 \%)$ & $11(32.4 \%)$ \\
\hline その他 & 4 & $(8.3 \%)$ & 7 & $(15.2 \%)$ & & $(20.5 \%)$ & 4 & $(9.5 \%)$ & $6(13.6 \%)$ & $1 \quad(2.9 \%)$ \\
\hline
\end{tabular}

かった点」でも「教授」について多くの調查対象者 が記述していたことを踏まえると，「良かった点」や 「改善点」といった違いに関わらず，「教授」は教師 志望学生の多くが批評する視点であると言える。

中山ら ${ }^{26)}$ は, 教育実習生の理科授業観察能力向上 を図るために授業観察ワークシートを開発し，教育 実習期間における実習生のワークシートを分析した 結果，「指導法」に関する記述が多かったことを明ら かにしている。また，中山らが開発したワークシー トを異なる年度で活用した阪元ら ${ }^{27)}$ や山口ら ${ }^{28)} に$ おいても，「指導法」についての記述が多かったこと (阪元ら),「指導法」について記述した人数が記述し なかった人数よりも多かったこと（山口ら）が明ら かにされている。本研究の「教授」は「指導法」に ほぼ該当すると考えられるため,「教授」について批 評する教師志望学生が多かったという本研究の結果 は，上記の一連の研究の結果と一致するものであっ たと言える。

また，「授業構成」については，すべての回で 5 割 に満たなかった。これより，教師志望学生は「授業 構成」に関する「改善点」を指摘することが困難で あると考えられる。

三島 ${ }^{29)}$ は，教育実習経験のある教職志望学生の授 業観察視点と, 観察視点に影響する授業・教師・子 どもイメージを検討するなかで, 学生は授業ビデオ を見る際，良い点や悪い点に関係なく，授業の核で ある本時の授業構成を重点的に見ていることを示唆 している。しかしながら, 本研究においては, 教師 志望学生は模擬授業について批評する際，「教授」に
ついてのことを中心に検討することが明らかとなっ た。三島が教育実習後の学生を対象として算数の授 業ビデオを見せることによって分析資料を収集して いるのに対して, 本研究では, 教育実習以前の学生 を対象とし，理科の模擬授業に览童役として参加し た学生の記述を分析の資料としているように，研究 対象にいくつかの相違がある。この点を踏まえると, 教師志望学生の観察視点の実態について, 教育実習 を経験する以前と以後では授業を観察する視点が異 なるということと，第三者の立場で参加した場合と 模擬授業のように自らが学習者として参加した場合 とでは観察視点が異なるということの，2つの可能 性が考えられる。これらの点については，教育実習 を経験した後の模擬授業を対象として調查を行うこ とや，教育実習を経験する前の観察視点をビデオ観 察の場合と比較検討するなど，別途調查を実施し， 検討する必要がある。

深さについて見ると，まず，「教授」については先 述したように「良かった点」では「小学校の授業全 般」について多く，「単元固有」が少ない傾向にあっ たものの,「改善点」では第 7 回と第 13 回を除く回 で同程度, あるいは「単元固有」の方が多い結果と なっていた。「改善点」を検討する際には単元固有の 内容と結びつけて検討しやすくなるものと考えられ る。

「授業構成」についても，各回における割合は低い ものの,「小学校の授業全般」と「単元固有」を比較 した場合には，第 13 回を除いた回で同程度あるいは 「単元固有」の方が多い結果となっていた。「授業構 
表 8 「改善点」の深さに関する記述人数

\begin{tabular}{lcccccc}
\hline & 第 1 回 & 第 5 回 & 第 7 回 & 第 9 回 & 第 12 回 & 第 13 回 \\
\hline 小学校の授業全般 & $33(68.8 \%)$ & $37(80.4 \%)$ & $27(61.4 \%)$ & $23(54.8 \%)$ & $23(52.3 \%)$ & $23(67.6 \%)$ \\
理科授業全般 & $25(52.1 \%)$ & $29(63.0 \%)$ & $25(56.8 \%)$ & $20(47.6 \%)$ & $18(40.9 \%)$ & $21(61.8 \%)$ \\
単元固有 & $31(64.6 \%)$ & $41(89.1 \%)$ & $31(70.5 \%)$ & $31(73.8 \%)$ & $29(65.9 \%)$ & $13(38.2 \%)$ \\
\hline
\end{tabular}

表 9 「改善点」の深さについての残差分析の結果

\begin{tabular}{|c|c|c|c|c|c|c|c|c|}
\hline \multirow{4}{*}{$\begin{array}{l}\text { レベルの記述の有無 } \\
\text { 小学校の授業全般 }\end{array}$} & \multicolumn{2}{|c|}{ 第 5 回 } & \multicolumn{2}{|c|}{ 第 9 回 } & \multicolumn{2}{|c|}{ 第 12 回 } & \multicolumn{2}{|c|}{ 第 13 回 } \\
\hline & $\chi^{2}(2)=$ & $\mathrm{p}<.01$ & $\chi^{2}(2)=$ & $p<.05$ & $\chi^{2}(2)=5.5$ & $;<\mathrm{p}<.10$ & $\chi^{2}(2)=$ & $\mathrm{p}<.05$ \\
\hline & 有 & 無 & 有 & 無 & 有 & 無 & 有 & 無 \\
\hline & 0.58 & -0.58 & -0.64 & 0.64 & -0.12 & 0.12 & $1.69^{+}$ & $-1.69^{+}$ \\
\hline 理科授業全般 & $-2.89^{* *}$ & $2.89 * *$ & $-1.79^{+}$ & $1.79^{+}$ & $-1.97^{*}$ & $1.97 *$ & 0.85 & -0.85 \\
\hline 単元固有 & $2.31^{*}$ & $-2.31^{*}$ & $2.43^{*}$ & $-2.43^{*}$ & $2.10^{*}$ & $-2.10^{*}$ & $-2.54^{*}$ & $2.54^{*}$ \\
\hline
\end{tabular}

成」についても「改善点」を検討する際には単元固 有の内容と結びつけて検討しやすくなるものと考え られる。

「教具」については，第 1 回と第 5 回では約 6 割, 第 7 回と第 9 回では約 3 割, 第 12 回と第 13 回では 約 4 割と, 回による相違が認められたものの,「良 かった点」と同様,「教材」よりも多い傾向にあっ た。このことから, 調查対象者においては, 授業を 批評する際, 観察・実験についてのことよりも教具 の活用方法や内容に注目していたと言える。

「教師の振る舞い」は，第 13 回で約 3 割の調查対 象者が記述していたが，他の回では約 1 割あるいは 1 割未満であった。また,「良かった点」の場合と同 様に,「教授」よりも少ない傾向にあり, 調査対象者 は教師行動について批評する際, 学習内容の指導に 関わる教師行為について批評していたと言える。

\section{2 .2 深さのみの回答傾向}

次に,「改善点」についても，どの「内容」カテゴ リの観点で記述していたかとは関係なく，どの「深 さ」のレベルで記述していたのかについて分析する ために，各回に抒いて「深さ」の各レベルの記述が 認められた人数を集計し，その結果を表 8 に示した。

表 8 の通り,すべての回で「小学校の授業全般」 についての記述人数の割合が 5 割以上であり特に第 1 回と第 13 回では 7 割近く, 第 5 回では 8 割であっ た。また，第 13 回を除くすべての回で「単元固有」 についての記述人数の割合が 6 割以上であり，特に 第 7 回と第 9 回では約 7 割, 第 5 回では約 9 割であっ た。「良かった点」と同様に, 各回におけるレベルご との記述人数を比較するために $\chi{ }^{2}$ 検定を行ったと
ころ, 第 12 回で記述人数の偏りが有意傾向, 第 5 回 と第 9 回と第 13 回で有意であった。残差分析（表 9) によると，第 5 回と第 9 回と第 12 回では「単元固有」 について記述した人数が有意に多く，第 13 回では有 意に少なかった。このことから，第 5 回と第 9 回と 第 12 回では,「改善点」について記述する際,「単元 固有」のレベルで記述した調查対象者が最も多かっ たと言える。

「改善点」で「深さ」の各レベルの記述人数に偏り が認められなかった第 1 回と第 7 回でも，「良かった 点」では「単元固有」についての記述人数が 2 割程 度であったのに対し，「改善点」では 6 割以上となっ ており，対象者の多くが「良かった点」よりも「改 善点」において「単元固有」に関する記述を行って いたと言える。

第 13 回は「単元固有」について記述した人数が有 意に少なかったが,「教師の振る舞い」についての記 述人数が多かったことが，この結果に対する理由の 手がかりのひとつとして考えられる。「教師の振る舞 い」には，授業者の姿勢や声の大きさなど, 教科に よる違いに関わらない，主に「小学校の授業全般」 のレベルに分類された記述が多く含まれていた。つ まり，第 13 回では多くの調査対象者が単元固有の内 容と関わることではなく，むしろ，「教師の振る舞 い」などの「小学校の授業全般」のレベルに該当す る内容について改善すべき重要な点が多くあると捉 えたため, 結果的に「単元固有」についての記述人 数が少なくなったのではないかと推察される。

以上のように,「改善点」については「単元固有」 について記述する調查対象者がほとんどの回で他の レベルよりも多いか同程度であったことが明らかと 
杉山・山崎：教師志望学生の理科授業についての批評視点に関する研究

なった。この結果は,「良かった点」についての分析 結果とは異なるとともに, 山口ら ${ }^{30)}$ とも異なる結果 である。本研究と山口らとでは調查の諸条件が異な ることは先に述べた通りであるが，ここで，山口ら が求めた「指導案を考える上で参考になる点」を調 查対象者による肯定的評価と捉え，これが，本研究 の「良かった点」の記述に対応していると考えた場 合, 教師志望学生は肯定的評価をする際には「単元 固有」の観点から検討することは難しいものの, 否 定的評価をする，すなわち問題点を見いだしたり改 善点を考えたりする際には「単元固有」の観点から の検討を行いやすいものと推察される。

\section{4. 結論と今後の課題}

本研究の目的は, 理科の模擬授業に児童役として 参加した教師志望学生の理科授業に関する授業批評 視点を明らかにすることであった。

分析の結果, 教師志望学生は, 児童役として参加 した模擬授業について批評する際，「教授」について のことを中心に検討することが明らかとなった。し かしながら，「教授」と同じく授業を構成する重要 な要素である「教材」や「授業構成」については, 「教材」について検討した学生は「良かった点」及び 「改善点」のいずれにおいても少なく，「授業構成」 については「改善点」において検討した学生が少な かった。「授業構成」に関するこの結果については, 「教授」が多かったという本研究の結果と先行研究で の指摘を踏まえて考察を行い，教育実習を経験する ことに伴う視点の変容と, 自らが児童役として参加 したことによる違いという $2 つ の$ 可能性について指 摘した。どちらの場合であっても，模擬授業が教育 実習の準備として行われるのであれば,「授業構成」 についての視点も養う必要がある。そのためには, 例えば熊谷 ${ }^{31)}$ のように，模擬授業において児童役の ほかに第三者の立場で観察する観察者役を設けるこ とによって，児童役の場合とは異なる視野に立って 授業を観察することができるものと考えられる。

また，授業についての「良かった点」を指摘する 際には単元固有の視点による批評が難しかったもの の，「改善点」を指摘する際にはそのような視点に よって批評を行っていたことが明らかとなった。教 授資料からの学習という学習方法に着目して分析を 行い, 教師志望学生が単元固有の教授技術などを学 習できない傾向にあることを明らかにした山口ら ${ }^{32)}$ の結果を踏まえると，教師志望学生にとっては，要 点が整理されたものから良い点を見いだすことは難 しく, その一方で, 課題が埋め込まれたものから改
善点を見いだすことは比較的容易であることが推察 される。もしそうであれば，教授資料からの学習や 熟練教師が行った授業からの学習だけでなく, 課題 が多く埋め込まれている学生の授業からの学習も, 理科の教え方を学ぶ方法として有効な手立ての 1 つ となると考えられる。

最後に，今後の課題について述べておきたい。省 察（reflection）を「解決」と「発見」に分けた木 原 ${ }^{33)}$ が, 教職 3 年目くらいまでは「発見」に力点を 置いてよいとしているように，多様な経験をするな かで自分なりの見方や考え方を蓄積していくことは 重要である。しかしながら, 学生の記述には「かも しれない」や「わからないけれど」といった記述が 散見され, 視点は持っているものの, それらは試行 錯誤のレベルであることがうかがえた。自分なりの 見方や考え方が試行錯誤のレベルであり，蓄積のレ ベルにまで至っていないのであれば, 養成段階にお いては，多様な学習機会を保障するだけでなく，試

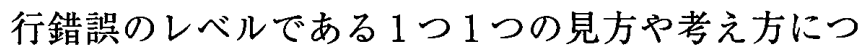
いて深める機会を持つことも必要であるのかもしれ ない。このような見解は仮説の段階であり, 今後, 記述内容の質的分析などによって教師志望学生の害 態に関する知見を蓄積した上で検討することが必要 である。以上のことを，今後の課題としたい。

\section{文献}

1）中央教育審議会：「今後の教員盖成・免許制度の在り 方について」, 2006

2）教育職員養成審議会：「新たな時代に向けた教員養成 の改善方策について」, 1997

3）木原成一郎, 日野克博, 米村耕平, 徳永隆治, 松田恵 示, 岩田昌太郎: 「教員養成段階で行う体育の模擬授 業の効果に関する事例研究一テスト映像を視聴した学 生が気づいた体育授業の要素一」, 広島大学大学院教 育学研究科紀要 第一部, 第 57 号, pp. 69-76, 2008

4）木原成一郎, 磯崎尚子, 磯崎哲夫：「教育実習生の小 学校体育科指導の心配に関する事例研究」, 日本教科 教育学会誌，第 25 巻，第 4 号, pp. 29-38, 2003

5）吉田安規良, 西島彩子：「教育実習生や若手教員の授業 実践力向上のための基礎研究一授業実践後の教育実習生 と中堅教員との自己分析内容の差に関する一事例一」, 琉球大学教育学部紀要，第 76 集, pp. 173-188, 2010

6）三崎 隆：「理科教員志望学生の資質能力向上に向け た授業改善に関する事例研究」, 北海道教育大学紀要 (教育学編), 第 56 巻, 第 2 号, pp. 107-116, 2006

7）佐藤勝幸, 片山隆志, 溝内正剛：「分かりやすい理科 授業に関する模擬授業体験後の意識の変化」, 鳴門教 育大学研究紀要, 第 22 巻, pp. 200-205, 2007 
8）伊佐公男，石井恭子：「授業作りと模擬授業を核とし た理科教材研究の実践報告」, 福井大学教育実践研究, 第 33 号, pp. 123-131, 2008

9）石井恭子, 山田吉英, 伊佐公男 : 小小学校教員養成課 程における「理科教材研究」の授業改革の試み」, 福 井大学教育実践研究, 第 35 号, pp. 43-56, 2010

10）德永好治：「大学生の授業批評能力と教職専門科目 「理科教材研究」との関連」, 日本理科教育学会研究紀 要, 第 24 巻, 第 1 号, pp. 1-8, 1983

11）中山 迅, 隅田 学, 阪元 聡, 宮本伸二郎, 山根研 一, 国生 尚, 隈元修一:「教育実習生の理科授業観 察能力を図るワークシートの開発」, 宮崎大学教育文 化学部附属教育実践研究指導センター研究紀要, 第 7 号, pp. 91-101, 2000

12）阪元 聡, 岩切宏樹, 隈元修一, 国生 尚, 岡田能 直, 中山迅, 隅田 学: 「教育実習生の理科授業観 察能力向上を図るワークシート利用に関する事例的研 究」, 宮崎大学教育文化学部附属教育実践研究指導七 ンター研究紀要, 第 8 号, pp. 7-16,2001

13）山口悦司, 中山迅，阪元 聡，岩切宏樹，国生 尚, 岡田能直, 隈元修一:「小学校教育実習生の理科 授業観察能力に関する継続的検討：ワークシートの基 礎的分析」, 宮崎大学教育文化学部附属教育実践研究 指導センター研究紀要, 第 9 号, pp. 91-97, 2002

14）土田 理, 八田明夫, 平 千力, 原田浩毅, 有村和 章, 二川美俊, 山元卓也, 内祥一郎, 今村 圭:「学 生の理科授業観察の視点を育てる学部と附属学校との 連携」, 鹿児島大学教育学部教育実践研究紀要, 第 14 巻, pp. 7-14, 2004

15）山口悦司, 稲垣成哲, 野上智行 : 「理科を教えること に関する教師の学習能力 : 小学校教師を目指す大学生 による教授資料からの学習を事例として」, 理科教育 学研究, 第 50 巻, 第 1 号, pp. 75-84, 2009
16）同上書 15)

17) Davis, E.A.: Preservice elementary teachers' critique of instructional materials for science, Science Education, 90(2), pp. 348-375, 2006

18）梅澤 実：「教育実習生における授業観察視点の変 容」, 鳴門教育大学学校教育研究紀要, 第 21 巻, pp. 171-181, 2006

19）三島知剛：「教師志望学生の授業観察視点の検討一授 業・教師・子どもイメージとの関連による検討一」, 日本教育工学会論文誌, 第 33 巻, 第 1 号, pp. 103110,2009

20）前掲書 11)

21）前揭書 14)

22）前掲書 15)

23）前揭書 15)

24）前掲書 15)

25）前掲書 10)

26）前掲書 11）

27）前掲書 12)

28）前掲書 13)

29）前掲書 19）

30）前掲書 15)

31）熊谷信順：「教育実習生の「学習指導技量」形成に寄 与する教育実習事前指導の構築（4）～模擬授業生徒 役による授業評定と教育実習指導教貝による学習指導 法評価の関係〜」, 東亜大学紀要, 第 11 号, pp. 51-62, 2010

32）前掲書 15）

33）木原俊行：「授業研究と教師の成長」, pp. 75-76, 2004, 日本文教出版.

(2011 年 11 月 11 日受付, 2012 年 3 月 15 日受理) 


\title{
Prospective Teachers' Critical Perspectives of Science Teaching: A Case Study of Trial Teaching Critiques.
}

\author{
Masatoshi SUGIYAMA ${ }^{1}$, Takahito YAMASAKI ${ }^{2}$ \\ ${ }^{1}$ Graduate School of Education (Ph.D. Course), Hiroshima University \\ ${ }^{2}$ Graduate School of Education, Hiroshima University
}

\begin{abstract}
SUMMARY
Trial teaching is thought to have an important role in the development of prospective teachers' competencies towards teaching practice. Many prior studies have focused on the competencies development of the prospective teacher who practiced trial teaching after they have become teachers. But he/she can experience trial teaching as a teacher much fewer times than as a student. This indicates that the prospective teacher, as a student in trial science teaching, has many opportunities to learn about methods of lesson planning and teaching practice. Therefore this study aimed to clarify what competencies he/she developed from the viewpoint of observation and critical perspectives of science teaching.

As a result of analyzing the 'content' and 'depth' of comments in the 'good points' and 'improving points' sections of 'comment cards', the following three points were revealed.

(1) When prospective teachers critiqued trial teaching, they tended to examine both 'good points' and 'improving points' focusing on individual teaching acts. In contrast, there were a small portion of them who examined both 'good points' and 'improving points' focusing on teaching materials, and there were a small portion of them who examined 'improving points' focusing on lesson structure.

(2) In the case of 'good points', many prospective teachers commented at the level of 'general elementary school teaching'; on the other hand, a small portion of them commented at the level of 'unit specific'.

(3) In the case of 'improving points', either more or a comparable number of prospective teachers commented at the level 'unit specific' than those who commented at the other levels.
\end{abstract}

$<$ Key words $>$ Teacher education, Elementary school science, Trial teaching, Teaching critique 